\title{
SISTEM PEMANTAUAN MOTOR INDUKSI 3 PHASE VIA ANDROID BERBASIS SMS GATEWAY
}

\author{
Brian Fernand, Suherli \\ Program Studi Teknik Elektro Fakultas TeknikUniversitas Pamulang \\ e-mail:Suherliboik@gmail.com
}

\begin{abstract}
ABSTRAK
Di antara gangguan yang terjadi pada motor listrik (motor induksi 3 phase) adalah karena beban lebih (overload) dan tegangan kurang (under voltage). Selain itu pengendali motor induksi umumnya masih dikendalikan dengan manual. Perusahaan di Indonesia masih banyak melakukan pengecekan motor dan mematikan/menghidupkan motor dilakukan oleh operator yang harus berada dekat mesin sehingga tidak efektif. Dalam tugas akhir ini penulis telah membuat alat dengan fungsi sistem telemetri dan telecontrol berbasis sms gateway dengan aplikasi android. Fungsi telemetri untuk pengecekan keandalan motor agar terhindar gangguan overload yakni dengan monitor Tegangan, Arus dan Suhu. Sedangkan telecontrol untuk mengontrol On/Off mesin. Hasil yang didapatkan pada alat sesuai dengan perancangan.Sensorsensor dalam alat ini berfungsi baik dengan memiliki Standar Error (SE) paling kecil 0,015. Sedangkan hasil pengiriman pesan sehingga dapat diterima melalui alat sms gateway ini memiliki keberhasilan 100\% menggunakan jaringan GSM Telkomsel dan XL dengan waktu ratarata 8,08 detik. Hal ini masih sesuai dengan acuan waktu pada standar ETSI (European Telecommunications Standart Institute) TR 102.444.
\end{abstract}

Kata kunci: Sms,sms gateway,Motor Induksi 3 Phasa, ETSI TR 102.444

\begin{abstract}
Among the disruptions thatoccur in electric motor (3 phase inductions motors) is due to overload and under voltage. In addition, induction motorcontrollers are generally still controlled by manual. Companies in Indonesia still do a lot of motor checking and turn off/turn on the motor is done by the operator who mush be near the engine so it is not effective. In this final project the author has made a tool with telemetry and telecontrol system function based on sms gateway with android application. Telemetry function to check the reliability of the motor to avoid overload disturbance that is with monitor voltage, current and temperature while telecontrol to control on/off engine. The results obtained on the tool in accordance with the design. The sensors in this tool work well with standard error (SE) at least 0,015. While the result of sending the message so that can be received throught sms gateway tool has $100 \%$ success using telkomsel and xI GSM network with an average time of 8,08 second. This is still in accordance with the time reference on the ETSI standard (European Telecommunications standart Institute). TR 102.444.
\end{abstract}

Keywords:SMS, Sms Gateway, 3 phase induction Motor, ETSI TR 102444 


\section{PENDAHULUAN}

erkembangan teknologi di Indonesia sudah semakin maju, Hal ini terlihat dari penggunaan teknologi informasi yang kini kian hari semakin meningkat. Teknologi yang terus berkembang akan mendorong setiap orang untuk menciptakan kreatifitasnya didalam kemajuan teknologi ini, Dimana kini cara penyampaian informasi dan komunikasi dapat terkirim secara cepat. Seiring perkembangan teknologi kini juga sudah ada smartphone yang menggunakan android sebagai operasi sistemnya. Android pun kini juga sudah sangat banyak diminati karena fiturnya yang powerfull dalam menghandle beberapa aplikasi yang membutuhkan spesifikasi tinggi

Dalam situasi tersebut di atas penulis telah membuat sistem pemantauan motor induksi 3 phase via android berbasis sms gateway yang menggunakan mikrokontroler sebagai pengendali dan modul sms gateway sebagai receivernya.

Sebab itu juga penulis membuat alat ini menggunakan sistem telemetri dan telecontrol. Telecontrol untuk mengontrol On/Off mesin dan telemetri untuk memonitoring suhu, tegangan, ampere dan keadaan motor jadi jika motor tersebut overload maka akan menyebabkan panas berlebihan sehingga kita dapat memantau panas tersebut dengan cara telemetri apakah panasnya melebihi batas name plate atau tidak, apabila melewati maka motor tersebut dapat dikatakan overload untuk menghindari kerusakan motor tersebut maka perlu penggatian motor dengan kapasitas daya yang lebih besar sesuai beban yg dibutuhkan dan motor yg akan diganti tersebut dapat digunakan untuk keperluan lainnya.

\section{II.DASAR TEORI}

\section{SMS Gateway}

Sms gateway adalah suatu platform yang yang menyediakan mekanisme untuk EUA(External User Application) menghantar dan menerima sms dari peralatan mobile seperti (HP, PDA phone dll). Sms gateway membolehkan EUA untuk berkomunikasi dengan telco SMSC (telkomsel, indosat dll) atau SMS platform untuk menghantar dan menerima pesan SMS dengan sangat mudah, Karena SMS gateway akan melakukan semua proses dan koneksi dengan telco. SMS gateway juga menyediakan EUA dengan interface yang mudah dan standar.

\section{Arsitektur Sms Gateway}

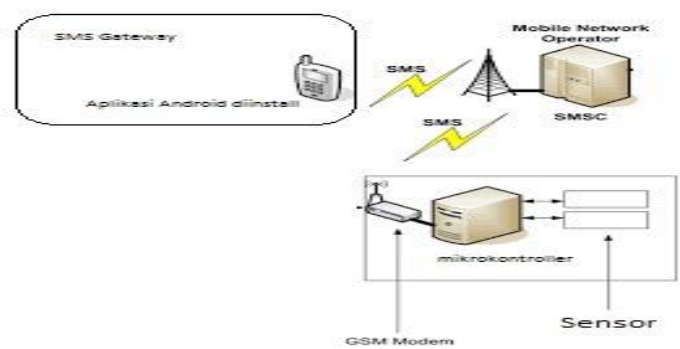

Gambar.1.Arsitektur Sms Gateway

\section{Penjelasan Gambar}

1. Dari sebelah kiri terdiri dari gambar jaringan GSM untuk SMS.

2. gambar sistem sms gateway dimana terdiri dari aplikasi android untuk memonitoring tegangan, arus dan suhu lalu GSM modem adalah HP itu sendiri yang sudah terinstall aplikasi sms gateway nya.

\section{Basic4 Android}

Basic4 android adalah software developer yang digunakan untuk membuat aplikasi android.software basic4Android ini bisa di bilang premium atau tidak free karena untuk mendapatkan aplikasi ini kita harus mengeluarkan uang terlebih dahulu dan harganya pun cukup mahal. Walaupun software ini premium tetapi dalam segi pembuatan aplikasinya software basic4Android ini lebih powerfull dalam menghandle aplikasi.Software basic4 android ini menggunakan bahasa basic 


\section{AVD Manager}

AVD (Android Virtual Devices) adalah konfigurasi dari emulator sehingga kita dapat menjalankan perangkat Android sesuai model yang dipilih, misal Android 1.5 atau 2.2 dan seterusnya.Untuk dapat menjalankan emulator, harus terlebih dahulu memiliki android SDK. Emulator ini nanti fungsi untuk mendasain tampilan aplikasi android sehingga kita dapat interface langsung bagaimana bentuk dan tampilan aplikasinya apakah sudah menarik atau belum.

\section{Modem GSM WAVECOM}

Modem WAVECOM berfungsi sebagaibagian pengiriman data dan sebagai Modul SMS Gateway. Modem GSMdigunakan karena dapat diakses menggunakankomunikasi data serial dengan baudrate yangdapat disesuaikan mulai dari 9600 sampaidengan 115200. Selain itu, modem GSM inimenggunakan catu daya DC $12 \mathrm{~V}$ dan tidakmemerlukan tombol ON untukmengaktifkannya, sehingga sangatr cocok untukdigunakan pada sistem yang berjalan terusmenerus. Berikut adalah gambar dari modem GSM WAVECOME

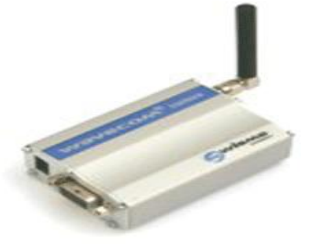

Gambar.2.Modem Wavecome

\section{AT-Command}

AT Command yang berarti Attention Command merupakan sekumpulan perintahperintahyang digunakan Komputer untuk mengakses modem handphone. Padamodem wavecom M1306B fastrack, perintahAT Command akan diterima melalui interfacemodem. Sedangkan kontroler berupamikrokontroler sebagai pengirim perintah akan mengirimkan perintah tersebut melalui serialinterface. Sehingga komunikasi antara modem dan kontroler adalah komunikasi secara serial, Cara penggunaan perintah AT Command adalah pengetikan perintah selalu diawali oleh at atau AT kemudian dilanjutkan denganperintah yang diinginkan. Jika perintah yang diberikan tidak ada kesalahan, maka HP akan memberikan jawaban dari perintah yang dikirim. Sebaliknya, jika terdapat kesalahan perintah, maka jawaban yang diterima oleh host pengirim adalah ERROR

\section{Sensor Suhu LM35}

Sensosr suhu LM35 adalah komponen elektronika yang memiliki fungsi untuk mengubah besaran suhu menjadi besaran listrik dalam bentuk tegangan, LM35 mempunyai keluaran impedansi yang rendah dan linieritas yang tinggi sehingga dapat dengan mudah dihubungkan dengan rangkaian kendali.

Meskipun tegangan sensor ini dapat mencapai 30 volt akan tetapi yang diberikan ke sensor adalah sebsar 5 volt, sehingga dapat digunakan dengan catu daya tunggal dengan ketentuan bahwa LM35 hanya membutuhkan arus sebesar $60 \mu \mathrm{A}$ hal ini berarti LM35 mempunyai kemampuan menghasilkan panas dari sensor yang dapat menyebabkan kesalahan pembacaan yang rendah yaitu kurang dari $0,5^{\circ} \mathrm{C}$ pada suhu 25ㅇ․

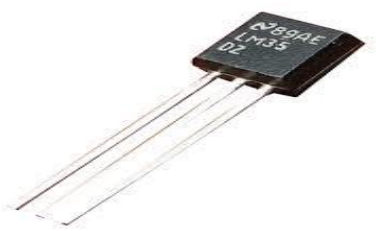

Gambar.3.Sensor Suhu LM35

\section{Sensor Arus SCT013}

Sensor SCT 013 merupakan sensor arus CT (Current Transformation). Cara kerjanya dengan meletakan sebuah kabel yang menuju ke beban dengan meletakan atau melewatkan pada sensor arus CT SCT 013 yang nantinya sensor arus SCT 013 akan mengirim data berupa data berbentuk 
analog yang kemudian akan dikirim pada modul kontroler arduino. Fungsi arduino disini digunakan untuk menerima data dari sensor SCT013 dan mengolahnya sehingga nanti akan muncul nilai arusnya.

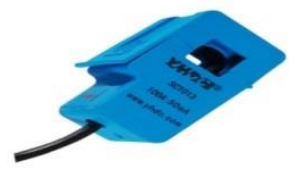

\section{Gambar 4.Sensor Arus SCT013}

\section{Arduino Uno}

Arduino uno adalah board mikrokontrler berbasis ATmega328. Uno memiliki 14 pin digital input/output (dimana 6 dapat digunakan sebagai output PWM). 6 input analog,resonator keramik $16 \mathrm{MHz}$,koneksi USB, jack listrik, header ISCP, dan tombol reset, Uno dibangun berdasarkan apa yang diperlukan untuk mendukung mikrokontroler, sumber daya bias menggunakan power USB (jika terhubung ke computer dengan kabel USB) dan juga dengan adaptor atau baterai.

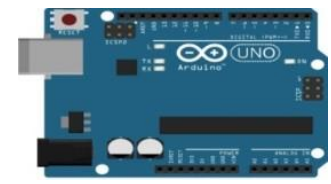

Gambar.5.Arduino Uno

\section{Sensor Tegangan ZMPT101B}

cara mengakses sensor tegangan $A C$ ZMPT101B untuk mengukur tegangan AC, sebenarnya banyak cara yang bisa dilakukan untuk mengukur tegangan $A C$ seperti halnya menggunakan sampling data dengan timer tertentu, ada juga yang dikonversi menjadi tegangan DC, dan banyak lainnya, disini dengan menggunakan cara kedua yaitu merubah tegangan AC tersebut menjadi DC, sehingga mudah untuk dibaca mikrokontroller, perlu diketahui bahwa adc tidak bisa membaca sinyal negatif maka dari itu tegangan negatif harus dinaikkan offsetnya ke 2.5 volt, sehingga ada space untuk nilai negatif dan positif, untuk menaikkan tegangan AC bisa digunakan rangkaian summing amplifier, namun pada modul sensor ini sudah include summing amplifier sehingga tidak perlu menggunakan rangkaian tersebut.

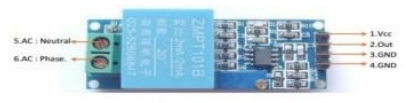

Gambar.6.Sensor Tegangan ZMPT101B

\section{III.METODOLOGI PENELITIAN}

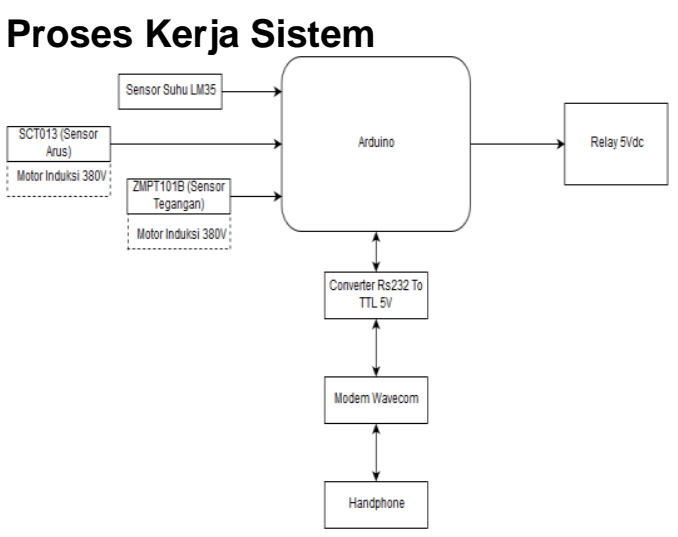

Gambar.7.Blok Diagram Alat

Dari gambar diatas dapat dijelaskan fungsi masing-masing blok yaitu sebagai berikut:

1. Arduino digunakan untuk sebagai pembaca sensor (sensor tegangan, sensor arus dan sensor suhu), pengolah data, membaca pesan, mengirim AT command dan control output relay.

2. Sensor LM35 adalah sebuah sensor yang digunakan untuk mengukur suhu.

3. Sensor SCT013 adalah sebuah sensor yang digunakan untuk mengukur arus.

4. Sensor ZMPT101B adalah sensor yang di gunakan untuk membaca tegangan. 
5. Relay adalah sebuah alat elektro mekanik yang bekerja dengan memanfaatkan teori arus listrik yang menghasilkan medan magnet.

6. Converter RS232 digunakan untuk mengkonversikan tegangan RS232 ke TTL dan sebaliknya.

7.

Modem wavecome adalah modem sms gateway digunakan untuk mengirim pesan dan menerima pesan.

8.

Handphone digunakan untuk mengirim perintah ke modem wavecome dan menerima feedback dari modem wavecom.

\section{Alur Kerja Sistem}

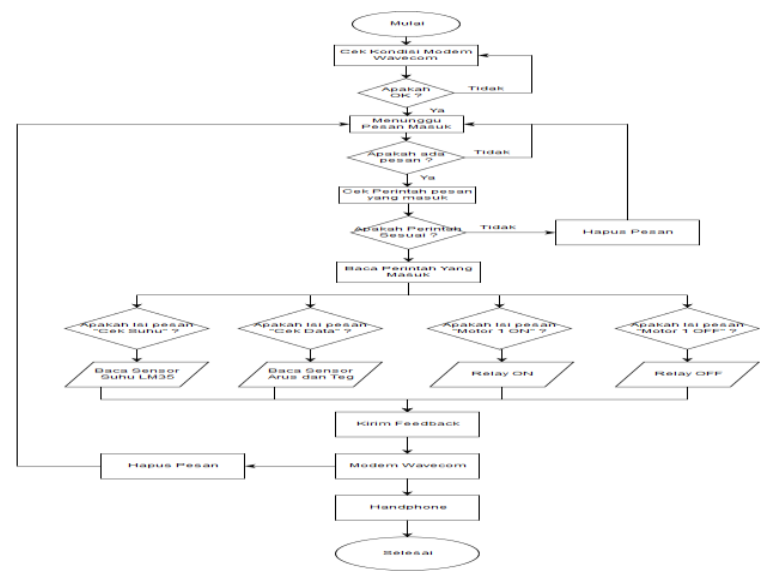

Gambar.8.Flowchart Kontroling Sistem

Alur kerja sistem ini adalah:

1. Pada saat sistem ON yaitu mendapatkan sumber supply sistem akan melakukan pengecekan kondisi pada modem waecom

2. Apabila pada saat arduino melakukan pengecekan pada modem wavecom lalu madem wavecom mengirimkan response "OK"

3. Arduino mennggu pesan masuk dan melakukan pengecekan pengecekan pesan yang masuk.

4. Apabila ada pesan yang masuk maka check perintah yang masuk, jika tidak ada pesan yang masuk sistem akan menunggu sampai ada pesan yang masuk.

5. Pesan yang masuk selanjutnya akan dibandingkan apakah pesan yang masuk sesuai dengan perintah yang telah dibuat atau tidak, jika sesuai maka arduino akan melakukan perintah tersebut sesuai sms yang masuk.

6. Setelah arduino menjalankan perintah sesuai sms yang masuk maka arduino akan mengirimkan feedback atau informasi kemodem wavecom yang nantinya akan dikirim kepada nomor yang telah telah di inputkan kedalam arduino.

7. Melakukan proses hapus pesan

8. Arduino kembali mennggu pesan yang masuk

\section{Perancangan Skematik Rangkaian}

Adapun skematik rangkaian dengan fungsi kerja masing-masing tiap komponen sebagai berikut:

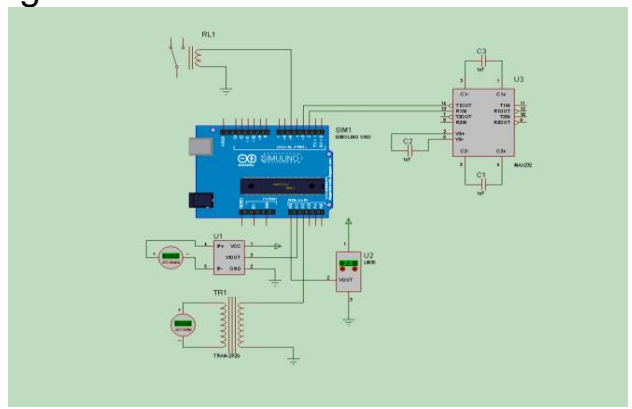

Gambar.9.Rangkaian Sistem

\section{Keterangan :}

1. Arduino : Berfungsi sebagai processor atau otak pengendali control

2. SCT-013 :Berfungsi sebagai sensor arus yang hasilnya akan dibaca oleh arduino.

3. ZMPT101B :Berfungsi sebagai sensor tegangan yang hasilnya akan dibaca oleh arduino.

4. LM35 :Berfungsi sebagai sensor suhu yang hasilnya akan dibaca oleh arduino, output berupa analog.

5. Converter RS232 to TTL : Berfungsi sebagai converter yang digunakan untuk komunikasi serial rs232 to ttl 


\section{Perancangan Wiring Diagram}

Perancangan ini terdiri dari modem waecome, converter RS232, Arduino uno, Solid state relay, PSU switching, sensor suhu Im35, sensor arus SCT013, sensor tegangan ZMPT101b, kontaktor magnet dan motor induksi 3 phase sebagai bebannya. Rangkaian wiring diagram ini dapat dilihat pada gambar dibawah ini

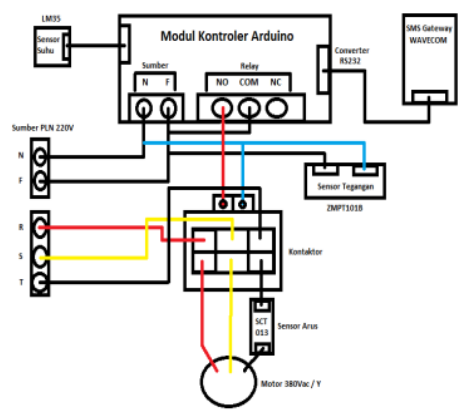

Gambar.10.Wiring Diagram

\section{Pembuatan Converter RS23}

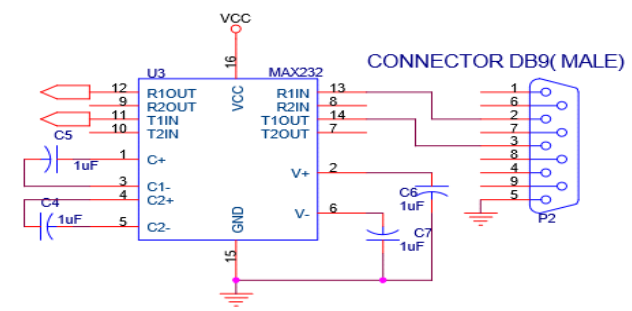

Gambar.11 Converter RS232

\section{Rangkaian Keseluruhan Sistem}

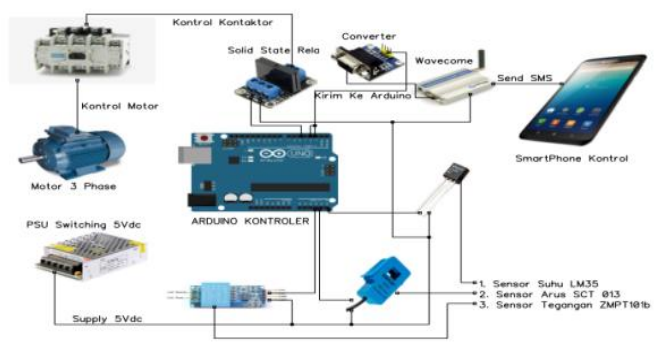

\section{Prinsip Kerja Rangkaian}

Perancangan rangkaian ini bekerja sesuai program yang telah dibuat.prinsip kerja pada rangkaian ini yaitu arduino sebagai processor, modem wavecom sebagai receiver sms, dan smartphone android sebagai transmiter sms. Pada awal arduino menyala maka semua program yg ada di arduino akan di eksekusi kemudian arduino menunggu info pesan sms dari receiver sms modem wavecom. mikro akan menunggu info pesan secara realtime sehingga apabila ada data sms yg masuk maka akan langsung dibaca oleh mikro. Pada sisi smartphone android digunakan sebagai transmiter atau pengirim yang digunakan untuk mengecek data, kontrol dan monitoring secara telecontrol dan telemetri.arduino akan membaca semua data pesan sms yang masuk sehingga bukan hanya sms dari pengguna saja melainkan dari sms lainnya. Sehingga maka dibuat lah sebuah perbandingan yang dimana jika ada sms dengan format Motor ON atau Motor OFF maka program baru akan mengeksekusi tetapi jika tidak sesuai format tersebut maka arduino akan mengabaikan pesan tersebut. Jika sms yang masuk dari pengguna yang formatnya sesuai maka arduino akan mengeksekusi program sesuai pesan yang masuk. Setelah arduino menjalankan perintah tersebut maka arduino akan mengirim feedback kembali dengan memerintahkan modem wavecom untuk mengirim feedback ke nomer pengguna bahwa motor sudah ON atau OFF

\section{Pembuatan Aplikasi SMS Gateway}

Tahap ini adalah proses pembuatan aplikasi sms gateway dari membuat koding pemrograman sampai jadi aplikasi. Pada tahap ini merupakan tahap akhir sebelum ke tahap pengujian.Pada proses ini pembuatan software android menggunakan aplikasi basic4android. Basic4Android merupakan 
sebuah tool RAD (Rapid Aplication Developement) yang digunakan untuk membuat aplikasi berbasis Android, dimana Android adalah sebuah sistem operasi untuk smartphone atau tablet yang sedang berkembang pesat dan begitu populer saat ini. Basic4Android terdiri framework, library, dan IDE yang terintegrasi dengan JAVA dan Android SDK.Berikut adalah tahap pembuatan aplikasinya.

1. Buka Aplikasi B4A

2. Klik save dan simpan project

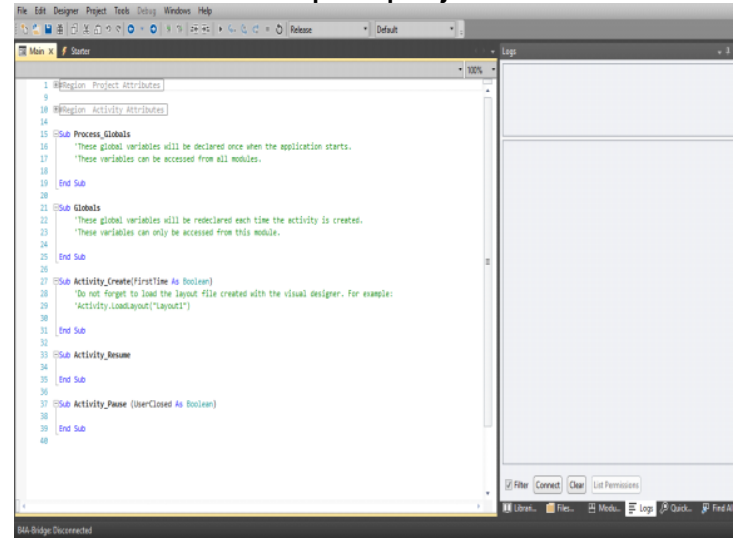

3. Buka project lalu klik open designer.

4. Pada desginer digunakan untuk membuat layout tampilan aplikasi

5. Gunakan 2 Button untuk ON dan OFF motor serta Label yang nanti digunkanan untuk notifikasi sms feedback dari modul sms gateway.

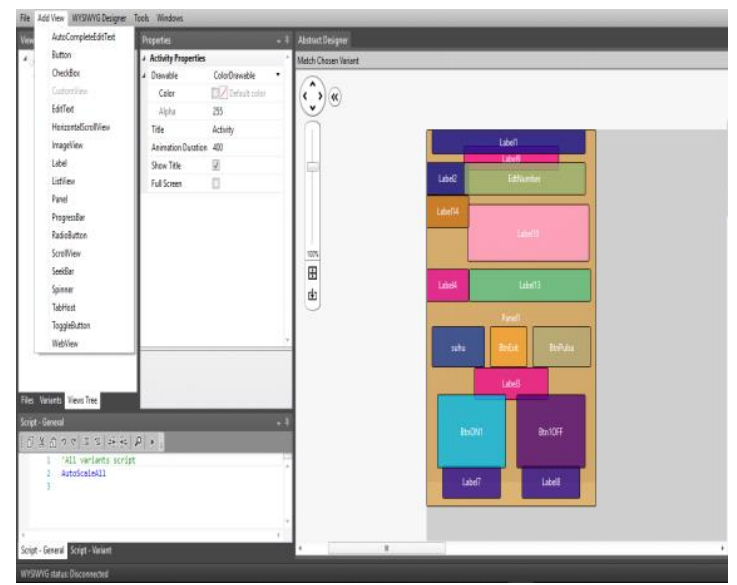

6. Setelah layout jadi dan selesai dibuat lalu kembali ke aplikasi B4A
7. Buat fungsi program pada masingmasing button untuk mengirim sms dengan format pesan yang sudah di tentukan untuk ON/OFF motor induksi 3 phase yang terhubung pada modul.

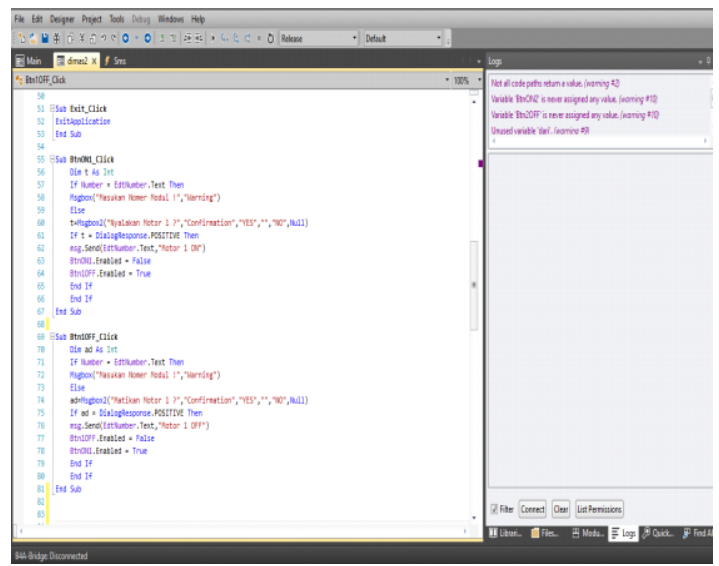

8. Pilih release lalu klik tombol play untuk membuat program tersebut menjadi aplikasi yang sudah di design dan di program tadi.

9. Jika sudah succes ambil aplikasinya pada folder project yang tersimpan dalam satu file program tadi lalu install di smartphone dan aplikasi siap digunakan

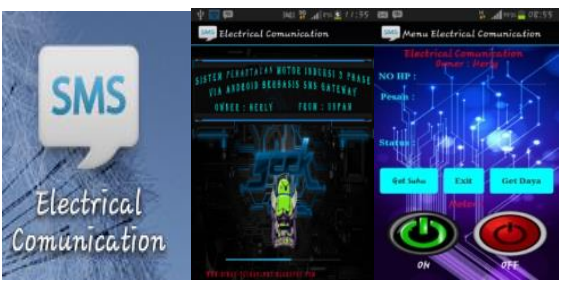

Gambar.13.Aplikasi Sms Gateway

\section{HASIL DAN PEMBAHASAN}

\section{Pengujian Tingkat Kesuksesan Pengiriman Pesan}

Pengujian keandalan sistem perangkat keras yang telah di buat dalam tugas akhir ini telah dilakukan menggunakan kartu XL dan Telkomsel dengan masing-masing sekali pengujian sebanyak 15 kali. 
Pemilihan menggunakan jaringan $\mathrm{XL}$ dan jaringan Telkomsel mewakili daerah cakupan jaringan terluas (Telkomsel), dan daerah cakupan dibawah dari pada jaringan Telkomsel, yakni penulis memilih jaringan XL.Berikut adalah tampilan hasil dari pengujian.

\section{Pengujian Menggunakan Kartu Telkomsel}

Tabel.1.Pengujian Menggunakan Kartu Telkomsel

\begin{tabular}{|c|l|l|c|}
\hline No & Perintah & Status - & Waktu (s) \\
\hline 1 & ON & Berhasil & 4,7 \\
\hline 2 & Get Suhu & Berhasil & 5,4 \\
\hline 3 & Get Daya & Berhasil & 10,1 \\
\hline 4 & OFF & Berhasil & 4 \\
\hline 5 & ON & Berhasil & 4 \\
\hline 6 & Get Suhu & Berhasil & 6,5 \\
\hline 7 & Get Suhu & Berhasil & 6,2 \\
\hline 8 & Get Daya & Berhasil & 9,4 \\
\hline 9 & Get Daya & Berhasil & 9,7 \\
\hline 10 & Get Daya & Berhasil & 12,2 \\
\hline 11 & Get Suhu & Berhasil & 8,2 \\
\hline 12 & Get Suhu & Berhasil & 6,8 \\
\hline 13 & Get Suhu & Berhasil & 6,5 \\
\hline 14 & Get Daya & Berhasil & 10,1 \\
\hline 15 & OFF & Berhasil & 4 \\
\hline
\end{tabular}

Pengujian Menggunakan Kartu XL

Tabel.2.Pengujian Menggunakan Kartu $\mathrm{XL}$

\begin{tabular}{|c|l|c|c|}
\hline No & Perintah & Status & Waktu (s \\
\hline 1 & ON & Berhasil & 6,3 \\
\hline 2 & OFF & Berhasil & 6,2 \\
\hline 3 & ON & Berhasil & 6,3 \\
\hline 4 & Get Suhu & Berhasil & 8,2 \\
\hline 5 & Get Daya & Berhasil & 11,2 \\
\hline 6 & Get Suhu & Berhasil & 7,9 \\
\hline 7 & Get Daya & Berhasil & 10,4 \\
\hline 8 & Get Suhu & Berhasil & 7,8 \\
\hline 9 & OFF & Berhasil & 5 '6 \\
\hline 10 & ON & Berhasil & 5,9 \\
\hline 11 & OFF & Berhasil & 6,3 \\
\hline 12 & ON & Berhasil & 6,1 \\
\hline 13 & Get Suhu & Berhasil & 8 \\
\hline 14 & Get Daya & Berhasil & 9,2 \\
\hline 15 & OFF & Berhasil & 5,3 \\
\hline
\end{tabular}

Dari 15 kali percobaan menggunakan kartu telkomsel terhadap perancangan sistem, rata-rata waktu yang di peroleh dari mulai pengiriman perintah menggunakan aplikasi sampai pada pengolah instruksi untuk mengendalikan motor induksi 3 phase menggunakan kar selama 7,18 sekon dan menggunakan kartu XI selatu telkomselma 7,38 sekon dengan tingkat kesuksesan $100 \%$. Hal ini masih sesuai dengan standar ETSI (European Telecommunications Standart Institute)TR 102.444 tentang sms performance di mana dikatakan bahwa "waktu pengiriman pesan singkat dari mobile station pengirim diterima ke penerima mobile station antara 6 sampai 8 detik". Jadi jika mengacu pada standar ETSI alat yang saya buat memenuhi standar.

\section{Pengambilan Data Menggunakan Alat Ukur manual}

Pengukuran manual baik tegangan, arus dan suhu masing-masing dilakukan sebanyak 10 kali, berikut hasil pengukurannya:

Tabel.3.Pengambilan Data Menggunakan Alat Ukur Manual

\begin{tabular}{|c|l|l|l|}
\hline $\mathbf{N}-$ & Besar Tegangan & Besar Arus & Besar suhu \\
\hline 1. & 395,1 Volt & 7,8 Ampere & $28^{\circ}$ Celcius \\
\hline 2. & 396,6 Volt & 7,9 Ampere & $28^{\circ}$ Celcius \\
\hline 3. & 392,6 Volt & 7,8 Ampere & $28^{\circ}$ Celcius \\
\hline 4. & 396,1 Volt & 7,8 Ampere & $28^{\circ}$ Celcius \\
\hline 5. & 395,9 Volt & 7,8 Ampere & $28^{\circ}$ Celcius \\
\hline 6. & 397,1 Volt & 8,0 Ampere & $28^{\circ}$ Celcius \\
\hline 7. & 392,2 Volt & 8,0 Ampere & $28^{\circ}$ Celcius \\
\hline 8. & 393,3 Volt & 7,9 Ampere & $28^{\circ}$ Celcius \\
\hline 9. & 390,7 Volt & 7,8 Ampere & $28^{\circ}$ Celcius \\
\hline 10. & 392,2 Volt & 7,8 Ampere & $28^{\circ}$ Celcius \\
\hline
\end{tabular}

Nilai pengukuran manual ini dijadikan referensi penulis untuk membandingkan dengan pengukuran yang dilakukan menggunakan aplikasi sms gateway

\section{Pengambilan Data Menggunakan Aplikasi Sms Gateway}

Tabel.4.Pengambilan Data Menggunakan Sms Gatewayl 


\begin{tabular}{|c|l|l|l|}
\hline $\mathrm{N} / \mathrm{F}$ & Besar Tegangan & Besar Arus & Besar Suhu \\
\hline 1. & 420,53 Volt & 7,66 Ampere & $30^{\circ}$ Celcius \\
\hline 2. & 426,22 Volt & 7,51 Ampere & $30^{\circ}$ Celcius \\
\hline 3. & 420,55 Volt & 7,46 Ampere & $31^{\circ}$ Celcius \\
\hline 4. & 432,87 Volt & 7,43 Ampere & $29^{\circ}$ Celcius \\
\hline 5. & 406,50 Volt & 7,68 Ampere & $31^{\circ}$ Celcius \\
\hline 6. & 422,98 Volt & 6,66 Ampere & $30^{\circ}$ Celcius \\
\hline 7. & 410,48 Volt & 6,40 Ampere & $30^{\circ}$ Celcius \\
\hline 8. & 420,12 Volt & 6,46 Ampere & $30^{\circ}$ Celcius \\
\hline 9. & 408,37 Volt & 6,51 Ampere & $30^{\circ}$ Celcius \\
\hline 10. & 414,84 Volt & 6,49 Ampere & $30^{\circ}$ Celcius \\
\hline
\end{tabular}

Dari tabel di atas dapat di ketahui pengukuran menggunakan aplikasi sms gateway pada motor memiliki nilai yang berbeda-beda baik tegangan, arus dan suhu. sehingga penulis melakukan perhitungan SE (Standar Error), perhitungan standar error sebagai berikut:

\section{Menghitung Standar Error (SE) Tegangan}

Tabel.5.Besaran Tegangan

\begin{tabular}{|c|l|}
\hline No- & Besar Tegangan \\
\hline 1. & 420,53 Volt \\
\hline 2. & 426,22 Volt \\
\hline 3. & 420,55 Volt \\
\hline 4. & 432,87 Volt \\
\hline 5. & 406,50 Volt \\
\hline 6. & 422,98 Volt \\
\hline 7. & 410,48 Volt \\
\hline 8. & 420,12 Volt \\
\hline 9. & 408,37 Volt \\
\hline 10. & 414,84 Volt \\
\hline
\end{tabular}

$>\quad$ Untuk mencari nilai standar error (SE) maka harus mencari nilai ratarata yaitu:

\subsection{3,46/10 = 418,34 Volt}

pada hasil pengukuran tegangan tersebut. Setelah dihitung mendapatkan nilai rara-rata pengukuran tegangan yaitu 418,34 Volt yang kita sebut mean.

kuadrat deviasi

Selanjutnya mencari nilai

Tabel.6.kuadrat deviasi Tegangan

\begin{tabular}{|c|c|c|c|}
\hline $\mathrm{N} / \mathrm{V}$ & Tegangan(Volt) & 7 Teg-Mean & - lollegl- mea \\
\hline 1. & 420,53 & 2,18 & 4,75 \\
\hline 2. & 426,22 & 7,87 & 61,93 \\
\hline 3. & 420,55 & 2,21 & 4,88 \\
\hline 4. & 432,87 & 14,53 & 211,12 \\
\hline 5. & 406,5 & $-11,84$ & 140,18 \\
\hline 6. & 422,98 & 4,64 & 21,52 \\
\hline 7. & 410,48 & $-7,86$ & 61,78 \\
\hline 8. & 420,12 & 1,78 & 3,17 \\
\hline 9. & 408,37 & $-9,97$ & 99,4 \\
\hline 10. & 414,84 & $-3,5$ & 10,05 \\
\hline & Jumlah & 0 & 618,78 \\
\hline
\end{tabular}

Dari data di atas maka dapat di hitung nilai sebagai berikut :

1.

$$
S^{2}=\sqrt{\frac{(\text { Teg }- \text { mean })^{2}}{n-1}}
$$

Jadi:

$$
S^{2}=618,78 / 10-1=68,75
$$

2. Nilai Standar Deviasi

$$
\mathrm{SD}=\sqrt{68,75}=8,29
$$

3.

$$
\mathrm{SE}=\frac{\sqrt{\mathbf{6 8 , 7 5}}}{10}=\sqrt{6,875}=2,62
$$

\section{Menghitung Standar Error (SE) Arus}

Tabel.7. Besar Arus

\begin{tabular}{|l|l|}
\hline No & \multicolumn{1}{|c|}{ Besar Arus } \\
\hline 1. & 7,66 \\
\hline 2. & 7,51 \\
\hline 3. & 7,46 \\
\hline 4. & 7,43 \\
\hline 5. & 7,68 \\
\hline 6. & 6,56 \\
\hline 7. & 6,4 \\
\hline 8. & 6,46 \\
\hline 9. & 6,51 \\
\hline 10. & 6,49 \\
\hline
\end{tabular}

Untuk mencari nilai standar error (SE) maka harus mencari nilai ratarata yaitu:

70,16/10 = 7,016 Ampere

padahasil pengukuran arus tersebut. 
Setelah dihitung mendapatkan nilai rararata pengukuran arus yaitu 7,016 ampere yang kita sebut mean. kuadrat deviasi

Selanjutnya mencari nilai

Tabel.8.Kuadrat Deviasi Arus

\begin{tabular}{|c|c|c|c|}
\hline No -1 & Arus (Ampere) & $\rightarrow$ Arus-Mean & 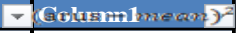 \\
\hline 1. & 7,66 & 0,64 & 0,4096 \\
\hline 2. & 7,51 & 0,49 & 0,2401 \\
\hline 3. & 7,46 & 0,44 & 0,1936 \\
\hline 4. & 7,43 & 0,41 & 0,1681 \\
\hline 5. & 7,68 & 0,66 & 0,4356 \\
\hline 6. & 6,56 & $-0,46$ & 0,2116 \\
\hline 7. & 6,4 & $-0,61$ & 0,3721 \\
\hline 8. & 6,46 & $-0,56$ & 0,3136 \\
\hline 9. & 6,51 & $-0,5$ & 0,25 \\
\hline 10. & 6,49 & $-0,53$ & 0,2809 \\
\hline & Jumlah & $-0,02$ & 2,8752 \\
\hline
\end{tabular}

Dari data di atas maka dapat di hitung nilai sebagai berikut :

1. Nilai varian (variance)

$$
S^{2}=\sqrt{\frac{(\text { Arus }- \text { mean })^{2}}{n-1}}
$$

Jadi: $S^{2}=2,8752 / 10-1=0,32$

2.

Nilai Standar Deviasi

$\mathrm{SD}=\sqrt{0,32}=0,56$

3.

Nilai Standar Error

SE $=\frac{\sqrt{\mathbf{0 , 3 2}}}{\mathbf{1 0}}=\sqrt{0,032}=0,18$

\section{Menghitung Standar Error (SE) Suhu}

Tabel.9.Besar Suhu

\begin{tabular}{|c|l|}
\hline No - & Besar Suhu \\
\hline 1. & $30^{\circ}$ Celcius \\
\hline 2. & $30^{\circ}$ Celcius \\
\hline 3. & $31^{\circ}$ Celcius \\
\hline 4. & $29^{\circ}$ Celcius \\
\hline 5. & $31^{\circ}$ Celcius \\
\hline 6. & $30^{\circ}$ Celcius \\
\hline 7. & $30^{\circ}$ Celcius \\
\hline 8. & $30^{\circ}$ Celcius \\
\hline 9. & $30^{\circ}$ Celcius \\
\hline 10. & $30^{\circ}$ Celcius \\
\hline
\end{tabular}

Untuk mencari nilai standar error (SE) maka harus mencari nilai ratarata yaitu:301/10 $=30,1$ Celcius

pada hasil pengukuran arus tersebut. Setelah dihitung mendapatkan nilai rara-rata pengukuran arus yaitu 30,1 Celcius yang kita sebut mean.

$>$ kuadrat deviasi

Tabel.10.Kuadrat Deviasi Suhu

\begin{tabular}{|c|l|l|l|}
\hline Ner & Suhu (Celcius) & Suhu-Mean & Coltimit \\
\hline 1. & 30 & $-0,1$ & 0.01 \\
\hline 2. & 30 & $-0,1$ & 0.01 \\
\hline 3. & 31 & 0,9 & 0,81 \\
\hline 4. & 29 & $-1,1$ & 1,21 \\
\hline 5. & 31 & 0,9 & 0,81 \\
\hline 6. & 30 & $-0,1$ & 0.01 \\
\hline 7. & 30 & $-0,1$ & 0,01 \\
\hline 8. & 30 & $-0,1$ & 0,01 \\
\hline 9. & 30 & $-0,1$ & 0,01 \\
\hline 10. & 30 & $-0,1$ & 0,01 \\
\hline & Jumlah & 0 & 2,9 \\
\hline
\end{tabular}

Dari data di atas maka dapat di hitung nilai sebagai berikut :

$4 . \quad$ Nilai varian (variance)

$S^{2}=\sqrt{ } \frac{(\text { Suhu }- \text { mean })^{2}}{n-1}$

Jadi:

$$
S^{2}=2,9 / 10-1=0,32
$$

5.

$$
\mathrm{SD}=\sqrt{0,32}=0,56
$$

Nilai Standar Deviasi

6. Nilai Standar Error SE $=\frac{\sqrt{\mathbf{0 , 3 2}}}{\mathbf{1 0}}=\sqrt{0,032}=0,18$

Dari hasil perhitungan standar error di atas tegangan memiliki $\mathrm{SE}=2,6$ Volt, Arus memiliki $\mathrm{SE}=0,18$ Ampere dan suhu memiliki $\mathrm{SE}=0,18^{\circ}$ Celcius dimana tegangan, arus dan suhu mendekati nilai SE $=0$ yang berarti sensor tegngan, sensor arus dan sensor suhu pada alat ini masih efektif untuk digunakan. 


\section{KESIMPULAN}

Berdasarkan pada perancangan, pengujian dan analisa yang telah dilakukan, maka dapat di ambil kesimpulan sebagai berikut:

1. Sistem pemantauan motor induksi 3 phase dapat dilakukan dengan sms gateway dimana fungsi Telemetri dan Telecontrol berfungsi dengan baik.

2. Pengukuran tegangan, arus dan suhu menggunakan sms gateway memiliki nilai Standar Error (SE) paling kecil sebesar 0,018 yang artinya sistem ini hampir tidak memiliki error sehingga handal untuk digunakan.

3. Waktu rata-rata pengiriman pesan menggunakan kartu telkomsel sampai pada instruksi selama 7,18 detik dan memiliki tingkat kesuksesan $100 \%$.

4. Waktu rata-rata penerimaan sms menggunakan kartu xl sampai pada instruksi selama 7,38 detik, dan memiliki tingkat kesuksesan $100 \%$

5. Waktu pengiriman pesan singkat dari mobile station pengirim diterima kepenerima mobile station rata-rata 0,08 detik yang artinya alat ini mendekati dengan standar ETSI TR 102.444

\section{UCAPAN TERIMAKASIH}

Dalam penulisan skripsi ini, penulis banyak mendapatkan bantuan baik lewat bimbingan, doa dan saran - saran yang sangat bermanfaat, sehingga penulis dapat menyelesaikan penulisan skripsi ini dengan baik. Untuk itulah penulis mengucapkan banyak berterimakasi yang sebesar besarnya kepada :

1. Bapak Drs. H. Darsono selaku Ketua Yayasan Sasmita Jaya Pamulang.

2. Bapak Ir. Dadang Kurnia, M.M. selaku Dekan Fakultas Teknik Universitas Pamulang.

3. Bapak Syaiful Bakhri,ST., M.Eng.Sc., Ph.D. selaku Ketua Program Studi Teknik Elektro Fakultas Teknik Universitas Pamulang.
4. Bapak Fahmi Islami Suud S.T., M.TI. Sebagai dosen pembimbing

5. Seluruh staf pengajar Fakultas Teknik Universitas Pamulang, yang telah mendidik penulis selama ini.

6. Ibu tercinta (Suillah), Istri(Try Wahyuni.S.TP) kakak (Yayah, Maryati, Siti Rohmah, M.Subli, M.Hedi ), Adik (Sujana) yang telah memotifasi dan mendidik penulis hingga memperoleh pendidikan yang lebih baik seperti sekarang ini.

Kepada pihak - pihak yang telah menolong dan membantu dalam penyelesaian penulisan skripsi ini, penulis hanya bisa berdoa, kiranya Allah SWT memberkahi kehidupan, keluarga, dan pekerjaan mereka. Amin

\section{DAFTAR PUSTAKA}

1.

ETSI, Technical

Report (TR)102.441 v1.1.1 "Analysis of the Short Message Service (SMS) and Cell Broadcast Service (CBS) For Emergency Messaging Aplication; Emergecy Messeaging;SMS and CBS',

$2 . \quad H a m m e r, \quad H$. (2013). "Pengertian Tentang Mesin-Mesin Listrik"

3. Langi, Shendy Irene. "Kipas Angin Otomatis Dengan Menggunakan Sensor Suhu”. Manado: UNSRAT, 2014.

4. Arif. 2014, Aplikasi Sms Gateway Presentasi Siswa Berbasis Web Dengan Php Dan Mysql, Aplikasi Sms Gateway, Universitas Yogyakarta.

5. Andriato Heri, 2013, Pemprograman Mikrokontroler AVR ATmega16 Menggunakan Bahasa C (Code Vision AVR), Informatikaoring KWH

$6 . \quad$ Utama, Navia. (2012). Sistem Monitoring KWH Meter dan

Universitas Pamulang |11 
Kalkulasi Biaya Pemakaian. Skripsi Surabaya: Jurusan Teknik Elektronika Politeknik Negri Surabaya (PENS-ITS).

7. Setiawan Afri, Mikrokontroller Atmega 1835 dan 16 Menggunakan BASKOM-AVR, 2012, Penerbit Andi.

8.

Panca. Frans Yahya, Sistem Pengendalian Robot Melalui SMS, Universitas Gunadarma, 2011

$9 . \quad$ Hamid. Marsyud, control AC Jarak Jauh Dengan Menggunakan Handphone. Universitas Negeri Makasar, $\underline{2010}$

10. Sulasno Ir, Teknik Konversi Energi Listrik Dan Sistem pengaturan, Graha Ilmu, Yogya karta, 2009.

11. Agusman, Aplikasi Pengontrolan Peralatan Rumah Berbasis SMS, Unversitas Komputer Indonesia, Bandung 2007 